\title{
Energetics of Finger Millet (Eleusine coracana L. Gaertn) Cultivation as Influenced by Integrated Nutrient Management
}

\author{
J.V. Harika, Sarath Kumar Duvvada, Sagar Maitra* and Tanmoy Shankar
}

M.S. Swaminathan School of Agriculture, Centurion University of Technology and Management, Paralakhemundi, 761211, Odissa, India

Corresponding author: sagar.maitra@cutm.ac.in (ORCID ID: 0000-0001-8210-1531)

Paper No. 841

Received: $17-12-2019$

Revised: 21-04-2020

Accepted: 25-05-2020

\begin{abstract}
Finger millets ((Eleusine coracana L. Gaertn) is one of the important small millets cultivated in India under subsistence farming in drylands. Though it is low demanding crop energy involvement is there in profitable raising of finger millet. Increase in energy use in agriculture production at a faster rate in India because of mechanization and enhancing chemical usage. To study the energy use in finger millet cultivation, a field trail was conducted at Bagusala Farm of M.S. Swaminathan School of Agriculture, Centurion University of Technology Management, Paralakhemundi, Odisha. The experiment was laid out in randomized complete block design (RCBD) with three replications and ten treatments. The treatment comprises of T1: control, T2: FYM@ $4 \mathrm{tha}^{-1}$,T3: FYM @ $8 \mathrm{t} \mathrm{ha}^{-1}, \mathrm{~T} 4: 100 \%$ RDF (40:20:20 kg ha-1 of N: $\mathrm{P}_{2} \mathrm{O}_{5}$ : $\left.\mathrm{K}_{2} \mathrm{O}\right), \mathrm{T} 5: 50 \%$ RDF + 4 t FYM, T6, 75\% RDF + 2 t FYM, T7: FYM 4 t ha-1 + Azospirillum@ 5 kg ha-1 ${ }^{-1}$ T8: FYM 8 t ha-1 + Azospirillum@ 5 kg ha-1 ${ }^{-1}$ T: $50 \%$ RDF + 4 t FYM + Azospirillum@ 5 kg ha-1 and T10: 75\% RDF + 2 t FYM + Azospirillum@ $5 \mathrm{~kg} \mathrm{ha}^{-1}$. The results revealed that all the energy parameters except energy productivity were significantly influenced by different treatments. The highest maximum energy input, gross energy output, net energy and energy intensity in term of economics were recorded maximum with application of $100 \%$ RDF and maximum energy use efficiency and energy productivity was noticed with application of FYM $8 \mathrm{t} \mathrm{ha}^{-1}+$ Azospirillum.

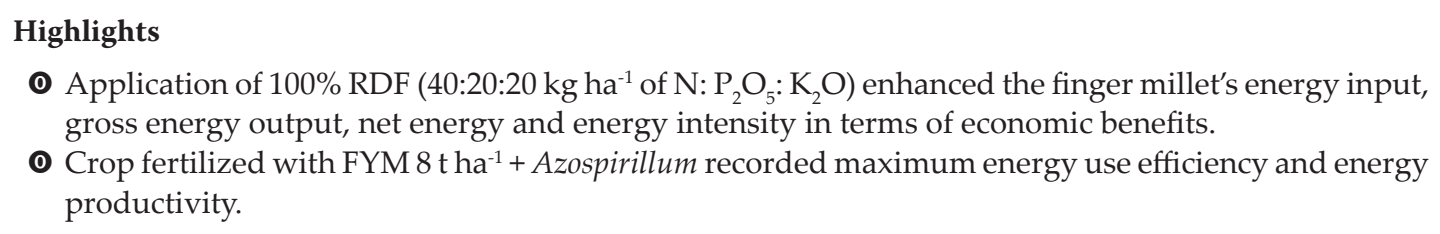

Keywords: Finger millet, FYM, Azospirillum, Energy use efficiency, Energy Productivity

Millets play a key role as major energy source and staple for the people living in arid regions of Asia and Africa. India is the leading producer of millets in the world. Among different millets, sorghum and pearl millet are known and major millets and rest of the millets cultivated in the country are small millets. The acreage of small millets in India is about 7.0 lakh ha and productivity is $633 \mathrm{~kg} \mathrm{ha}^{-1}$ (Maitra 2020). In dry regions of India, different small millets are cultivated in subsistence farming by smallholders (Maitra et al. 1998), of which finger millet (Eleusine coracana L. Gaertn) contributes about
$80 \%$ of production. Nutrient management play a pivotal role in enhancement of productivity of finger millet and integrated nutrient management is the best option to provide desired nutrients by using organic manure, biofertilizers and chemicals (Maitra et al. 2019). Energy plays an important role in agricultural production (Khambalkar et al. 2010). The demand for energy by agriculture is increasing day by day to feed the growing population all over the world which impacts the farmer's health and agro-ecosystem. Judicious use of energy in agriculture not only reduces ill-effects 
on environment but also leads the farming practices towards sustainability (Dalgaard et al. 2001; Nasso et al. 2011). A higher input of energy accounts for more costs, which significantly reduces the net return of the farms and is a challenging issue for the policy makers. Among all the inputs supplied, nitrogen fertilizer intakes the more amount of energy andso to reduce the energy intake in farming, the supply of nitrogen can be supplemented by applying organic manures and biofertilizers which may help to reduce energy involvement in agriculture (Ghosh et al. 2016). All the mechanical operations and inputs used in crop production require energy which may vary among the farmers. In modern agriculture, the use of machinery became more due to unavailability of skilled labour for different operations during the right period. The energy use pattern, profitability and involvement of energy resources should be studied to evaluate the feasibility of raising a crop on sustainable basis. In the present study, an initiative has been taken up to evaluate the energetics of finger millet cultivation as influenced by integrated nutrient management.

\section{MATERIALS AND METHODS}

The present study was conducted during kharif season at Bagusala Farm, of M.S. Swaminathan School of Agriculture, Centurion University of Technology Management, Paralakhemundi, Gajapati, Odisha. The average minimum and maximum temperature varied from $21.4^{\circ} \mathrm{C}$ to $27.5^{\circ}$ $\mathrm{C}$ and $30.1^{\circ} \mathrm{C}$ to $45.8^{\circ} \mathrm{C}$, respectively. During the crop growing period, the total rainfall of 1047.6 $\mathrm{mm}$ was received. The soil of experimental field was sandy clay loam in texture, slightly acidic in reaction ( $\mathrm{pH}$ 6.5), low in available nitrogen $(104 \mathrm{~kg}$ $\left.\mathrm{ha}^{-1}\right)$ and medium in available phosphorous $(23 \mathrm{~kg}$ $\mathrm{ha}^{-1}$ ) and potassium (196 kg ha-1). The experiment was adopted in randomized complete block design (RCBD) with three replications and ten treatments namely., T1: control, T2: FYM @ 4 t ha- ${ }^{-1}$,T3: FYM @ $8 \mathrm{t} \mathrm{ha}^{-1}$, T4: $100 \%$ RDF (40:20:20 kg ha-1 of N: $\mathrm{P}_{2} \mathrm{O}_{5}$ : $\left.\mathrm{K}_{2} \mathrm{O}\right), \mathrm{T} 5: 50 \% \mathrm{RDF}+4 \mathrm{t} \mathrm{FYM}, \mathrm{T} 6,75 \% \mathrm{RDF}+2 \mathrm{t}$ FYM, T7: FYM 4 t ha-1 + Azospirillum@ $5 \mathrm{~kg} \mathrm{ha}^{-1}$, T8: FYM 8 t ha $^{-1}+$ Azospirillum@ 5 kg ha-1, T9: 50\% $\mathrm{RDF}+4 \mathrm{t}$ FYM + Azospirillum@ $5 \mathrm{~kg} \mathrm{ha}^{-1}$ and T10: $75 \%$ RDF + 2 t FYM + Azospirillum@ 5 kg ha-1. FYM was analysed to find out the nitrogen content and applied to main plot as per treatment before 2 weeks prior to transplanting. The crop was transplanted in main field with spacing row to row and plant to plant distance $20 \mathrm{~cm} \times 20 \mathrm{~cm}$ adopting square planting method and the plot size was $4 \mathrm{~m} \times 3$ $\mathrm{m}$. The half of the nitrogen and entire quantity of phosphorus and potassium were applied at time of transplanting as a basal dose. The remaining half of nitrogen was applied as top dressing at three weeks after transplanting. The slurry of Azospirillium was prepared and the seedlings for the respective treatments were treated by root dipping for 30 minutes before transplanting. The energy input was worked out by adding of energy equivalents for all inputs used in system represented in Table 1. The gross output energy was calculated by multiplying the produce with grain and straw energy. The energy indices were determined by using the following formula.

Energy efficiency $(\%)=\frac{\text { Gross energy output }\left(\mathrm{GJ} \mathrm{ha}^{-1}\right)}{\text { Total energy input }\left(\mathrm{GJ} \mathrm{ha}^{-1}\right)}$

Energy productivity $\left(\mathrm{Kg} G J^{-1}\right)=$

$$
\frac{\text { Grain }+ \text { Straw yield }\left(\mathrm{Kg} \mathrm{ha}^{-1}\right)}{\text { Total energy input }\left(\mathrm{GJ} \mathrm{ha}^{-1}\right)}
$$

Energy intensity in Economic terms $\left(\mathrm{MJ} \mathrm{Rs.}^{-1}\right)=$

$$
\frac{\text { Gross energy output }\left(\mathrm{MJ} \mathrm{ha}^{-1}\right)}{\text { Cost of cultivation (Rs. ha } \left.{ }^{-1}\right)}
$$

Net energy $=$ Gross energy output $\left(\mathrm{GJ} \mathrm{ha}^{-1}\right)-$ Energy input (GJ ha' $\left.{ }^{-1}\right)$

The data were statistically analysed by using Microsoft Office Excel 2010 software. The analysis procedure as suggested by Gomez and Gomez, 1984 was followed for RCBD. Statistical significance was tested by computing the $\mathrm{F}$ value at $5 \%$ level of probability and critical difference was calculated for comparison of treatments mean.

\section{RESULTS AND DISCUSSION}

\section{Energetics}

The energetics parameters like energy input (GJ $\left.h^{-1}\right)$, Gross energy output (GJ ha-1), Net energy (GJ $\left.\mathrm{ha}^{-1}\right)$, Energy use efficiency (\%), Energy productivity $\left(\mathrm{Kg} \mathrm{GJ}^{-1}\right)$ and Energy intensity in economic terms 
Table 1: Energy equivalents for various input and output energy forms

\begin{tabular}{|c|c|c|c|}
\hline Component & Unit & Energy equivalent $(\mathrm{MJ} / \mathrm{h})$ & Source \\
\hline Adult male & Man per hour & 1.96 & Soni et al. (2013) \\
\hline Adult female & Female per hour & 1.60 & Soni et al. (2013) \\
\hline Cultivator & Hour $(\mathrm{h})$ & 3.135 & Nassiri and Singh (2009) \\
\hline Tractor & Hour & 64.80 & Devasenapathy et al. 2009 \\
\hline Sprayer & Hour & 0.502 & Nassiri and Singh (2009) \\
\hline Diesel & $\mathrm{L}$ & 56.30 & Nassiri and Singh (2009) \\
\hline $\mathrm{N}$ & $\mathrm{Kg}$ & 60.60 & Kuswardhani et al. (2013) \\
\hline $\mathrm{P}_{2} \mathrm{O}_{5}$ & $\mathrm{Kg}$ & 11.10 & Chaudhary et al. (2009) \\
\hline $\mathrm{K}_{2} \mathrm{O}$ & $\mathrm{Kg}$ & 6.70 & Chaudhary et al. (2009) \\
\hline FYM & $\mathrm{Kg}$ & 0.30 & Kizilaslan (2009) \\
\hline Bio fertilizer & $\mathrm{Kg}$ & 10 & Singh and Mittal (1992) \\
\hline Pesticide & $\mathrm{Kg}$ & 199.0 & Brar et al. (2015) \\
\hline Seed & $\mathrm{Kg}$ & 14.70 & Tuti et al. (2012) \\
\hline Grain & $\mathrm{Kg}$ & 14.70 & Tuti et al. (2012) \\
\hline Straw & $\mathrm{Kg}$ & 12.50 & Tuti et al. (2012) \\
\hline
\end{tabular}

Table 2: Energetics of finger millet cultivation as influenced by integrated nutrient management

\begin{tabular}{|c|c|c|c|c|c|c|}
\hline Treatments & $\begin{array}{l}\text { Energy } \\
\text { input (GJ } \\
\text { ha-1) }^{-1}\end{array}$ & $\begin{array}{l}\text { Gross } \\
\text { energy } \\
\text { output (GJ } \\
\text { ha }^{-1} \text { ) }\end{array}$ & $\begin{array}{l}\text { Net energy } \\
\left(G J h^{-1}\right)\end{array}$ & $\begin{array}{l}\text { Energy use } \\
\text { efficiency (\%) }\end{array}$ & $\begin{array}{l}\text { Energy } \\
\text { productivity } \\
\left(\mathrm{Kg} \mathrm{GJ}^{-1}\right)\end{array}$ & $\begin{array}{l}\text { Energy intensity } \\
\text { in economic terms } \\
\text { (MJ Rs. }{ }^{-1} \text { ) }\end{array}$ \\
\hline $\mathrm{T}_{1}$ Control (no fertilizer) & 2.93 & 37.70 & 34.77 & 12.87 & 991.53 & 2.14 \\
\hline $\mathrm{T}_{2} \mathrm{FYM} 4 \mathrm{t} \mathrm{ha}^{-1}$ & 2.95 & 38.03 & 35.08 & 12.91 & 994.00 & 1.86 \\
\hline $\mathrm{T}_{3}$ FYM $8 \mathrm{tha}^{-1}$ & 2.95 & 38.72 & 35.77 & 13.14 & 1011.58 & 1.67 \\
\hline $\mathrm{T}_{4} 100 \% \mathrm{RDF}$ & 5.74 & 77.41 & 71.67 & 13.49 & 1035.51 & 3.82 \\
\hline $\mathrm{T}_{5} 50 \% \mathrm{RDF}+4 \mathrm{t} \mathrm{FYM}$ & 4.35 & 53.43 & 49.07 & 12.28 & 944.53 & 2.46 \\
\hline $\mathrm{T}_{6} 75 \% \mathrm{RDF}+2 \mathrm{t} F Y M$ & 5.05 & 66.67 & 61.63 & 13.21 & 1016.10 & 3.17 \\
\hline $\mathrm{T}_{7} \mathrm{FYM}_{4} \mathrm{t}_{\text {ha }}{ }^{-1}+$ Azospirillum & 3.01 & 40.94 & 37.93 & 13.60 & 1046.70 & 1.93 \\
\hline $\mathrm{T}_{8} \mathrm{FYM} 8 \mathrm{t} \mathrm{ha}^{-1}+$ Azospirillum & 3.01 & 42.45 & 39.43 & 14.09 & 1084.46 & 1.77 \\
\hline $\begin{array}{l}\mathrm{T}_{9} 50 \% \mathrm{RDF}+4 \mathrm{t} \mathrm{FYM}+ \\
\text { Azospirillum }\end{array}$ & 4.40 & 53.99 & 49.58 & 12.27 & 943.34 & 2.40 \\
\hline SEm.. & 0.57 & 1.02 & 0.98 & 0.32 & 73.16 & 0.41 \\
\hline $\mathrm{CD}(\mathrm{P}=0.05)$ & 1.68 & 3.01 & 2.89 & 0.95 & NS & 1.21 \\
\hline
\end{tabular}

(MJ Rs. $\left.{ }^{-1}\right)$ of finger millet were calculated and presented in Table 2 .

Significantly the highest energy input was noticed with application of $100 \%$ RDF (5.74 GJ ha-1) which was followed by $75 \%$ RDF + 2t FYM (5.05 GJ ha$\left.{ }^{1}\right)$ and the lowest energy input was recorded with no fertilizer (2.93 GJ ha-1). The application of more amount of fertilizer with $100 \%$ RDF which resulted in highest energy input compared to others. Gross energy output was significantly influenced with different treatments. The maximum gross energy output was noticed with application of $100 \%$ RDF (77.41 GJ ha-1) and minimum gross energy output was found in control (37.70 GJ ha-1). The higher straw and grain yield in 100\% RDF increases the gross energy output. Net energy was significantly influenced among the different treatments in which higher net energy was noticed with application of $100 \%$ RDF (71.67 GJ ha ${ }^{-1}$ ) and lower net energy was found in control (34.77 GJ ha-1). This is due to positively increment in gross output with regards to input energy. The energy use efficiency was recorded with highest value of $14.09 \%$ with FYM 8 t ha ${ }^{-1}+$ Azosprillum which remained at par with FYM 4 t ha-1 + Azosprillum (13.60 \%), 100\% RDF (13.49 $\%), 75 \%$ RDF + 2t FYM (13.21 \%), and FYM 8 t ha $^{-1}$ $(13.14 \%)$ and the lowest value was noticed under $50 \%$ RDF + 4 t FYM + Azospirillum (12.27 \%). This is due to increase in output energy with regards to input energy which leads to increase the energy use efficiency. There was no significant difference was noticed in energy productivity among different 
treatments. The highest energy productivity was found with FYM $8 \mathrm{t} \mathrm{ha}^{-1}+$ Azosprillum $\left(1084 \mathrm{Kg} \mathrm{GJ}^{-}\right.$ $\left.{ }^{1}\right)$ followed by $100 \%$ RDF (1035.51 Kg GJ ${ }^{-1}$ ) while the lowest energy productivity was recorded with application of $50 \%$ RDF + 4 t FYM + Azospirillum $\left(943.34 \mathrm{Kg} \mathrm{GJ}^{-1}\right)$. The maximum energy intensity in term of economics was recorded with $100 \%$ RDF (3.82 $\mathrm{MJ} \mathrm{Rs.}^{-1}$ ) which remained statistically at par with 75 \% RDF + 2 t FYM (3.17 MJ Rs. ${ }^{-1}$ ), 50 \% RDF + 4 t FYM (2.46 MJ Rs. $\left.{ }^{-1}\right), 50 \% \mathrm{RDF}+4$ t FYM + Azospirillum (2.40 MJ Rs. ${ }^{-1}$ ) and minimum energy intensity in term of economics was noticed with FYM 8 t ha $^{-1}$ (1.67 MJ Rs. $\left.{ }^{-1}\right)$. The higher gross output with considerable cost of cultivation reported the higher energy intensity in term of economics.

\section{CONCLUSION}

Application of $100 \%$ RDF resulted in maximum energy input, gross energy output, net energy and energy intensity in term of economics while minimum energy input, gross energy output, net energy and energy intensity in term of economics under control (no fertilizer). The highest energy use efficiency and energy productivity was noticed with application of FYM $8 \mathrm{t} \mathrm{ha}^{-1}+$ Azospirillum and lowest energy use efficiency and energy productivity $50 \%$ RDF + 4 t FYM + Azospirillum .

\section{REFERENCES}

Brar, A.S., Buttar, G.S., Jhanji, D., Sharma, N., Vashist, K.K., Mahal, S.S., Deol, J.S. and Singh, G. 2015. Water productivity, energy and economic analysis of transplanting methods with different irrigation regimes in Basmati rice (Oryza sativa L.) under north-western India. Agricultural Water Management, 158: 189-195.

Chaudhary, V.P., Gangwar, B., Pandey, D.K. and Gangwar, K.S. 2009. Energy auditing of diversified Paddy-wheat cropping systems in Indo-Gangetic plains. Energy, 34: 1091-1096.

Dalgaard, T., Halberg, N. ans Porter, J.R. 2001. A model for fossil energy use in Danish agriculture used to compare organic and conventional farming. Agric. Ecosyst. Environ., 87(1): 51-65.

Devasenpathy, P., Senthilkumar G. and Shanmugam, P.M. 2009. Energy management in crop production. Indian Journal of Agronomy, 54: 80-90.

Ghosh, B.N., Dogra, P., Sharma, N.K., Alam, N.M., Singh, R.J. and Mishra, P.K. 2016. Effects of resource conservation practices on productivity, profitability and energy budgeting in maize-wheat cropping system of Indian sub-Himalayas. Proceedings of the National Academy of Sciences, India Section B: Biological Sciences, 86(3): 595-605.
Gomez, K.A. and Gomez, A.A. 1984. Statistical procedures for Agricultural Research. Second Edition (IRRI John Wiley and Sons Publication: New York).

Khambalkar, V.P., Pohare, J., Katkhede, S., Bunde, D. and Dahatonde, S. 2010. Energy and economic evaluation of farm operations in crop production. Journal of Agricultural Science, 2: 191

Khambalkar, V.P., Pohare, J., Katkhede, S., Bunde, D. and Dahatonde, S. 2010. Energy and economic evaluation of farm operations in crop production. Journal of Agricultural Science, 2: 191.

Kizilaslan, H. 2009. Input-output energy analysis of cherries production in Tokat Province of Turkey. Appl. Energy, 86: 1354-1358.

Kuswardhani, N., Soni, P. and Shivakoti, G.P. 2013. Comparative energy input-output and financial analyses of greenhouse and open field vegetable production in West Java, Indonesia. Energy, 53 :83-92.

Maitra, S, Reddy, M.D. and Nanda, S.P. 2020. Nutrient Management in Finger Millet (Eleusine coracana L. Gaertn) in India. International Journal of Agriculture, Environment and Biotechnology, 13(1): 13-21.

Maitra, S. 2020. Potential horizon of brown-top millet cultivation in drylands: A review. Crop Res. 55(1 \& 2): 57-63.

Maitra, S., Ghosh, D.C. Sounda, S., Jana, P.K. and Roy, D.K. 1998. Effect of seed treatment on growth and productivity of finger millet under rained lateritic belt of West Bengal. Indian Agriculturist, 42(1): 37- 43

Nassiri, S.M. and Singh, S. 2009. Study on energy use efficiency for paddy crop using data envelopment analysis (DEA) technique. Appl. Energy, 86: 1320-1325.

Nasso, D.N.N., Bosco, S., Bene, D.C., Coli, A., Mazzoncini, M. and Bonari, E. 2011. Energy efficiency in longterm Mediterranean cropping systems with different management intensities. Energy, 36: 1924-1930.

Singh, S. and Mittal, J.P. 1992. Energy in Production Agriculture, Mittal Publications, New Delhi, pp. 8-9.

Soni, P., Taewichit, C. and Salokhe, V.M. 2013. Energy consumption and $\mathrm{CO}_{2}$ emissions in rain-fed agricultural production systems of Northeast Thailand. Agric. Syst., 116: $25-36$.

Tuti, M.D., Ved Prakash, B.M., Pandey, R., Bhattacharyya, D., Mahanta, J.K., Bisht, M.K., Mina, B.L., Kumar, N., Bhatt, J.C. and Srivastva, A.K. 2012. Energy budgeting of colocasia-based cropping systems in the Indian subHimalayas. Energy, 45: 986-993. 